\title{
Influence of individual $H X T$ transporters in xylose fermentation by recombinant Saccharomyces cerevisiae strains
}

\author{
Davi Ludvig Gonçalves', Akinori Matsushika², Belisa Bordin de Sales ${ }^{1}$, Margareth Patiño Lagos ${ }^{1 *}$, Tetsuya Goshima², \\ Boris Stambuk
}

From 5th Congress of the Brazilian Biotechnology Society (SBBIOTEC)

Florianópolis, Brazil. 10-14 November 2013

\section{Background}

Lignocellulosic biomass is an attractive raw material for bioethanol production since it is an abundant and renewable feedstock that does not compete with food and feed production [1]. Xylose is the most abundant pentose present on these feedstocks, and although $S$. cerevisiae cannot readily ferment this sugar, the overexpression of the genes for xylose reductase (XR) and xylitol dehidrogenase (XDH) from $P$. stiptis and xylulokinase (XK) from S. cerevisiae allows the utilization of xylose [2]. However S. cerevisiae also lacks specific transporters for this sugar and thus the uptake of xylose is carried out by native hexose transporters encoded by the HXT1-HXT7 genes [3]. In the present report we analyzed the impact of individual $H X T$ transporters on xylose fermentation by recombinant $S$. cerevisiae yeast strains overexpressing the genes for $\mathrm{XR}, \mathrm{XDH}$ and XK [4].

\section{Methods}

Cultivations were perfomed in rich (YP) or synthetic complete (SC) medium containing the required sugars and when necessary, $2 \%$ Bacto agar, $0.5 \mathrm{mg} / \mathrm{l}$ aureobasidin A and $200 \mathrm{mg} / \mathrm{l}$ Geneticin were added to the medium. The chromosome-integrative plasmid pAURXKXDHXR [4] containing PGK promoters for overexpression of XR, XDH and XK was digested with $B s i \mathrm{WI}$ and then chromosomally integrated into the AUR1 locus of the yeast strains. HXT1, HXT2, HXT5 and HXT7 genes were obtained by PCR from S288c S. cerevisiae genomic DNA and cloned individually into a pPGK multicopy plasmid [5], and these plasmids were

'Departamento de Bioquímica, Centro de Ciências Biológicas, Universidade Federal de Santa Catarina, Florianópolis, SC, Brazil

Full list of author information is available at the end of the article transformed into the strains lacking all $H X T$ genes or individual $H X T$ genes, respectively. Anaerobic batch fermentations were performed at $30^{\circ} \mathrm{C}$ in closed $50-\mathrm{ml}$ bottles with a magnetic stir bar and $100 \mathrm{rpm}$. Assays with $2-6 \%$ of glucose, xylose or both sugars were performed. During fermentation cell growth was monitored and samples were removed for further analysis. Glucose, xylose, ethanol, xylitol, glycerol, and acetic acid were determined by HPLC as previously described [4].

\section{Results and conclusion}

The deletion of individual $H X T$ genes had no detectable effect on glucose fermentations, but these knockout strains ferment xylose poorly, even under glucose plus xylose conditions. The low-affinity $H X T 1$ permease allowed the maximal consumption of sugars and ethanol production rates during xylose plus glucose co-fermentation, but was incapable to allow xylose consumption when this sugar was the only carbon source. The highaffinity $H X T 7$ permease allowed efficient xylose fermentation, but during xylose plus glucose co-fermentation this permease showed a clear preference for glucose. While the HXT5 permease performed bad with glucose and did not allow xylose utilization, the moderately high-affinity $H X T 2$ permease was a transporter that allowed xylose consumption with the same rates as glucose, even under co-fermentation conditions, but had the drawback of producing stuck fermentations. Thus, our results indicate that new approaches to engineer selected $H X T$ transporters to increase their affinity towards pentoses, or to avoid their sugar-induced degradation, are promising strategies to improve second generation bioethanol production by xylose-fermenting yeasts. 


\section{Acknowledgements}

This work was funded by the Brazilian agencies CNPq, FAPESC and FINEP, and by the Japanese International Cooperation Agency (JICA).

\section{Authors' details}

${ }^{1}$ Departamento de Bioquímica, Centro de Ciências Biológicas, Universidade Federal de Santa Catarina, Florianópolis, SC, Brazil. ${ }^{2}$ Biomass Technology Research Center (BTRC), National Institute of Advanced Industrial Science and Technology (AIST), 3-11-32 Kagamiyama, Higashi-hiroshima, Hiroshima

739-0046, Japan

Published: 1 October 2014

\section{References}

1. Caspeta L, Buijs NAA, Nielsen J: The role of biofuels in the future energy supply. Energy Environ Sci 2013, 6:1077-1082.

2. Kim SR, Park YC, Jin YS, Seo JH: Strain engineering of Saccharomyces cerevisiae for enhanced xylose metabolism. Biotechnol Adv 2013, 31:851-861.

3. Saloheimo A, Rauta J, Stasyyk OV, Sibirny AA, Penttila M, Ruohonen L: Xylose transport studies with xylose-utilizing Saccharomyces cerevisiae strains expressing heterologous and homologous permeases. Appl Microbiol Biotechnol 2007, 74:1041-1052.

4. Matsushika A, Watanabe S, Kodaki T, Makino K, Sawayama S: Bioethanol production from xylose by recombinant Saccharomyces cerevisiae expressing xylose reductase, NADP+-dependent xylitol dehydrogenase, and xylulokinase. J Biosci Bioeng 2008, 105:296-299.

5. Kang YS, Kane J, Kurjan K, Stadel JM, Tipper DJ: Effects of expression of mammalian $G$ alpha and hybrid mammalian-yeast $G$ alpha proteins on the yeast pheromone response signal transduction pathway. Mol Cell Biol 1990, 10:2582-2590.

doi:10.1186/1753-6561-8-S4-P209

Cite this article as: Gonçalves et al:: Influence of individual HXT transporters in xylose fermentation by recombinant Saccharomyces cerevisiae strains. BMC Proceedings 2014 8(Suppl 4):P209.

\section{Submit your next manuscript to BioMed Central} and take full advantage of:

- Convenient online submission

- Thorough peer review

- No space constraints or color figure charges

- Immediate publication on acceptance

- Inclusion in PubMed, CAS, Scopus and Google Scholar

- Research which is freely available for redistribution

Submit your manuscript at www.biomedcentral.com/submit 